\title{
Egypt's COVID-19 Recent Happenings and Perspectives: A Mini-Review
}

\begin{abstract}
AbdulRahman A. Saied ${ }^{1,2 \star}$, Asmaa A. Metwally ${ }^{3}$, Norah Abdullah Bazekh Madkhali ${ }^{4}$, Shafiul Haque ${ }^{5,6}$ and Kuldeep Dhama ${ }^{7}$

${ }^{1}$ Department of Food Establishments Licensing (Aswan Branch), National Food Safety Authority (NFSA), Aswan, Egypt, ${ }^{2}$ Touristic Activities and Interior Offices Sector (Aswan Office), Ministry of Tourism and Antiquities, Aswan, Egypt,

${ }^{3}$ Department of Surgery, Anesthesiology, and Radiology, Faculty of Veterinary Medicine, Aswan University, Aswan, Egypt, ${ }^{4}$ College of Nursing, Jazan University, Jazan, Saudi Arabia, ${ }^{5}$ Research and Scientific Studies Unit, College of Nursing and Allied Health Sciences, Jazan University, Jazan, Saudi Arabia, ${ }^{6}$ Bursa Uludağ University, Faculty of Medicine, Bursa, Turkey, ${ }^{7}$ Division of Pathology, ICAR-Indian Veterinary Research Institute, Bareilly, India
\end{abstract}

The coronavirus disease 2019 (COVID-19) pandemic, caused by severe acute respiratory syndrome coronavirus 2 (SARS-CoV-2), has affected countries across the world. While the zoonotic aspects of SARS-CoV-2 are still under investigation, bats and pangolins are currently cited as the animal origin of the virus. Several types of vaccines against COVID-19 have been developed and are being used in vaccination drives across the world. A number of countries are experiencing second and third waves of the pandemic, which have claimed nearly four million lives out of the 180 million people infected globally as of June 2021. The emerging SARS-CoV-2 variants and mutants are posing high public health concerns owing to their rapid transmissibility, higher severity, and in some cases, ability to infect vaccinated people (vaccine breakthrough). Here in this mini-review, we specifically looked at the efforts and actions of the Egyptian government to slow down and control the spread of COVID-19. We also review the COVID-19 statistics in Egypt and the possible reasons behind the low prevalence and high case fatality rate (CFR\%), comparing Egypt COVID-19 statistics with China (the epicenter of COVID-19 pandemic) and the USA, Brazil, India, Italy, and France (the first countries in which the numbers of patients infected with COVID-19). Additionally, we have summarized the SARS-CoV-2 variants, vaccines used in Egypt, and the use of medicinal plants as preventive and curative options.

Keywords: COVID-19, Egypt, case fatality rate, SARS-CoV-2, vaccines, medicinal plants, health care workers, mutations

\section{INTRODUCTION}

In late December 2019, a new coronavirus (SARS-CoV-2) emerged in Wuhan, Hubei Province, China (1). According to some reports, it first appeared on November 17, 2019 (2). Later on, severe acute respiratory syndrome coronavirus 2 (SARS-CoV-2) has widely and rapidly spread in China and several other countries, causing an outbreak of acute viral pneumonia and a pandemic disease called coronavirus disease 2019 (COVID-2019) (3,4) (Figure 1). At the time of the writing of this review article, the SARS-CoV-2 has infected nearly 180 million and killed around 4 million (2.2\% mortality rate) people worldwide. SARS-CoV-2 belongs to the genus Betacoronavirus, 


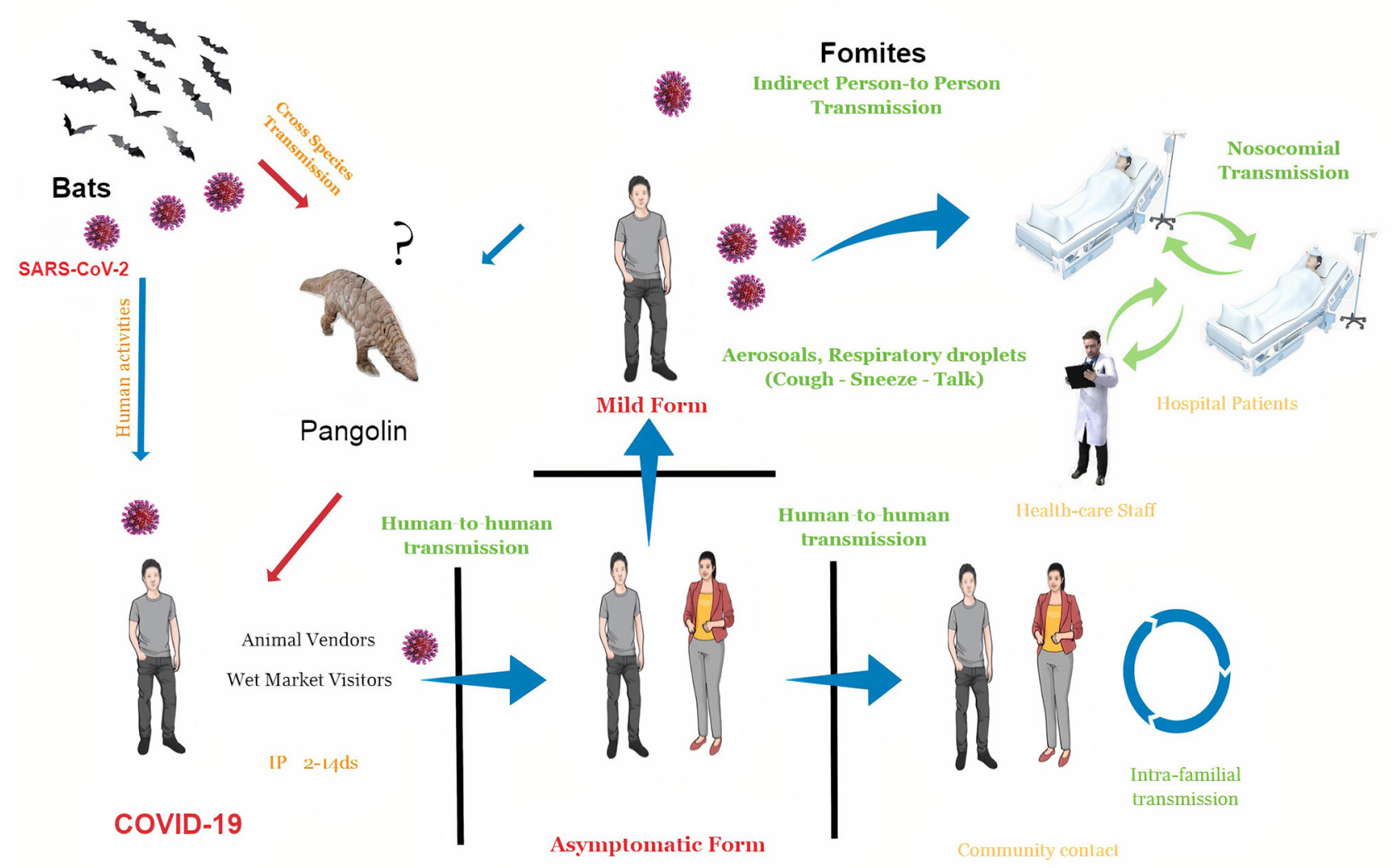

FIGURE 1 | The schematic diagram of coronavirus disease 2019 (COVID-19) spread. Severe acute respiratory syndrome coronavirus 2 (SARS-CoV-2) is most likely spread from bats to people through intermediate hosts like pangolins or other wild animals sold at Huanan local Seafood Wholesale market, Wuhan, Hubei Province, China. Human-to-human transmission is established once the virus has been transferred in this manner. Nosocomial transmission (viral spread between persons inside hospitals, such as doctors, nurses, and patients) and intrafamilial transmission (viral spread between family members) are the most common kinds of human-to-human transmission.SARS-CoV-2 is transmitted through aerosol droplets and fomites. The disease has a 2- to 14-day incubation period and can cause mild, moderate, severe, or even asymptomatic forms.

subgenus Sarbecovirus, subfamily Orthocoronavirinae, family Coronaviridae, and order Nidovirales $(1,5)$. SARS-CoV-2 binds to angiotensin-converting enzyme 2 (ACE-2) receptor in the body cells, primarily lung tissue via the $\mathrm{S}$ protein (the viral structural proteins, spike shape), which could be modified by transmembrane proteinase-serine 2 (TMPRSS2), facilitating the entry of viral particles into the cell (6). COVID-19 pandemic returns our minds to the ongoing ability of viral spillover from animals to cause severe disease in humans (1). Emerging zoonotic viruses continuously circulate in animal reservoirs, and events like cross-species jumping and zoonotic spillover might complicate the containment of viral pandemics. It is not new to say that SARS-CoV-2 will not be the last virus transmitted in this way. Coronaviruses (CoVs) are genetically diverse, undergo frequent mutations and recombinations $(5,7)$, and can jump from animals to humans, from humans to animals, and between animals $(8,9)$. The human genome evolves at a rate of $1 \%$ every 8 million years, whereas, many animal RNA viruses evolve at a rate of $1 \%$ every day, allowing us to predict the emergence of new zoonotic viruses (10). COVID-19 outbreak is thought to have begun in the Huanan local Seafood Wholesale market in Wuhan, Hubei province, central China (1). However, a very recent report indicated that the origin of COVID-19 might be from the wild animal farms that provided this market with animals (11). SARS-CoV-2 may be transmitted directly from bats (to sellers and market vendors) or utilizing intermediate animal hosts [e.g., pangolins (12) or other wild animals (13) to humans], and its zoonotic concerns are being investigated yet to reach any conclusion. SARS-CoV-2 has been detected in few animal species, such as dogs, cats, gorillas, tigers, lions, puma, and minks. Most of these instances have been linked to humanto-animal transmission; nevertheless, the virus was observed to spread rapidly among minks, with reports of mink-to-human transmission events $(9,14-16)$. Close human-animal contact and often coexistence are still common in rural African communities with virtually no barriers to wild environments (e.g., tropical forests), as they are in China. According to both the number of infected people and the geographic scope of the epidemic areas, 
TABLE 1 | Severe acute respiratory syndrome (SARS), Middle East respiratory syndrome (MERS), and coronavirus disease 2019 (COVID-19).

\begin{tabular}{|c|c|c|c|}
\hline Disease & SARS & MERS & COVID-19 \\
\hline Date of emergence & November, 2002 & June, 2012 & December, 2019 \\
\hline Origin & Guangdong, China & Jeddah, Saudi Arabia & Wuhan, China \\
\hline Number of infected persons & 8,422 & 2,499 & $135,471,700$ \\
\hline CFR\% & $10.88 \%(916)$ & $34.45 \%(861)$ & $2.16 \%(2,931,916)$ as of Apr 9, 2021 \\
\hline
\end{tabular}

COVID-19 has overwhelmingly surpassed SARS and Middle East respiratory syndrome (MERS) (17) (Table $\mathbf{1}$ and Figure 2).

Since mid-December 2019, human-to-human transmission has occurred among close contacts. SARS-CoV-2 is transmitted via the airborne route (spreads through the air) in indoor environments (18) and aerosol route (19) coming from either the breath, coughing, and sneezing of patients or aerosolization of the virus-laden aerosols from the feces or urine of a patient while using the toilet (20). Pathogen-bearing droplets of all sizes can travel 7-8 m (21). In addition, SARS-CoV-2 can remain stable for several days in aerosols and surfaces (18). The virusladen droplets settle out or evaporate at rates that depend on their size, speed of the gas cloud, and the ambient environment properties (temperature, humidity, and airflow) (22). As the liquid content of droplets evaporates, several droplets become so small that they can pass through the air, bringing their viral content meters and tens of meters away from their source. The fecal-oral route is also reported as a route for SARS-CoV-2 transmission $(23,24)$ besides the fecal-aerosol transmission in a high-rise building in Guangzhou, China (25). The virus also can transmit from pregnant moms to their newborns via the transplacental and vertical routes $(26,27)$. COVID-19 causes asymptomatic infections and mild to severe pneumonia $(28,29)$. Its incubation period is $2-14$ days (range from 2 to 7 ) (30), death period is 17-24 days.

Symptoms include fever, cough, dyspnea, muscle ache, confusion, headache, sore throat, rhinorrhea, chest pain, diarrhea, nausea, vomiting, anosmia, and dysgeusia (31). Acute respiratory distress syndrome (ARDS), cytokine storm, cardiovascular complications, pulmonary acute stroke, gastrointestinal and neurological manifestations, and kidney dysfunction are serious conditions that may lead to multiple organ failure and death $(29,32-34)$. Prevention and control measures include early diagnosis, contact tracing, strengthening of medical facilities, and adopting frequent handwashing, appropriate room ventilation, open space, social distancing, sanitization of protective apparel and proper use, disinfection of toilet areas, strict quarantine, travel restrictions, and minimizing the number of people sharing the same environment. To limit the danger of exposure to the airborne virus, public personal protection measures such as wearing masks, adopting social distancing rules, and avoiding crowded areas are critical $(29,35,36)$.

To provide insight into the current scenario of the COVID-19 outbreak in Egypt, we used data from publicly accessible and upto-date sources such as published papers, WHO reports, official newspapers of Egypt, and other reports.

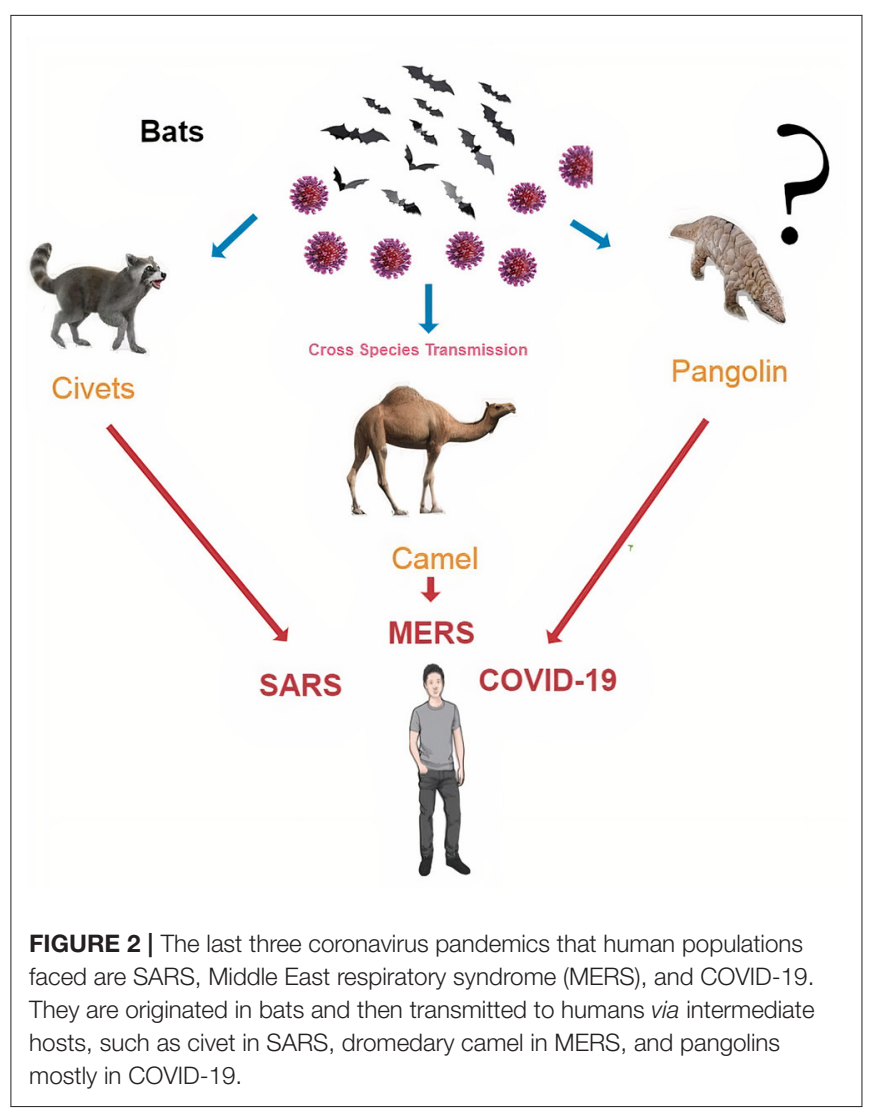

\section{HOW DID EGYPT RESPOND TO COVID-19?}

The following is a rundown of a timeline of main incidents that occurred recently in Egypt to slow down and control the spread of the virus: on January 26, 2020, all the flights between China and Egypt have been suspended, while the suspension of all flights began from March 19, 2020. Schools, universities, and all public areas where people gatherings could happen were closed. As of March 21, 2020, all mosques and churches were closed. Aside from that, external and internal tourism to tourist cities, including Luxor and Aswan, where cases have been confirmed among Egyptians and tourists onboard a floating hotel cruise, has been halted to prevent illness transmission. A curfew was enforced till the end of March 2020.

Campaigns of "Stay home, stay safe" for adopting social distancing on the social networks were performed extensively to create COVID-19 pandemic awareness among the public. 
Campaigns were launched in media and on the roads to promote frequent handwashing, cough etiquette, the use of personal protection equipment (e.g., facemasks), reducing hand-to-face contact, avoiding sharing bedrooms and towels, diminishing air conditioner (AC) use, and avoiding crowding in public transport. Also, the public was motivated to report fever and other symptoms, risk factors for coronavirus infection, including travel history to the affected areas, and close contacts with confirmed or suspected cases. The Egyptian Ministry of Health and Population $(\mathrm{MOH})$ has launched a specialized hotline to provide medical counseling services for people in need. All festivals were suspended, and the number of employees was reduced in non-vital works to encourage public sector employees to work remotely, minimizing their contact and contamination of workplaces with the virus. The Egyptian government has carried out a massive disinfection program prioritizing all squares, workplaces, touristic locations, touristic hotels (permanent and floating), and restaurants, using chlorinecontaining disinfectants as lipid solvents. Due to the economic impact of closure and curfew, all the previous restrictions were relaxed (37) to varying degrees and according to the epidemiological status, with tightening of movement restrictions on the largest religious festivities of 2020, such as during Eid Al-Fitr and Eid Al-Adha to avoid large gatherings and prevent SARS-CoV-2 infection. Egypt is a developing country, and tighter movement restrictions will undoubtedly have a short-term impact on its economy, particularly the tourism sector, a cornerstone of the economy of Egypt, which has been passed through difficult times since the 25 January revolution until the emergence of COVID-19 in Egypt. Therefore, Egypt became partially open, allowing for continued labor under more sanitary conditions, particularly in establishing large-scale projects. Thanks to the early measures implemented, Egypt could contain the rate of infection and minimize fatalities.

\section{CORONAVIRUS DISEASE 2019 STATISTICS IN EGYPT}

Egypt confirmed its first case of COVID-19 on February 14, 2020, as the first African country had reported a confirmed case (Figure 3). From February 14, 2020, to April 9, 2021, 208,876 laboratory-confirmed infections, including 12,362 deaths (5.92\%) by SARS-CoV-2 infection (Figure 4), were recorded according to the official website of the Egyptian MOH (https://www.care. gov.eg/EgyptCare/index.aspx accessed Apr 9, 2021) specialized for the news of COVID-19 outbreak in Egypt. Although, the incidence and morbidity rates are low, Egypt ranks the 7th country in case fatality rate (CFR 5.92\%) with COVID-19 (Figures 5A,B). Egypt had high importation risk of SARSCoV-2 cases from China (38), and by mid-March 2020, local transmission has been established (39). Genomes shared by Egypt with the GISAID ${ }^{1}$ are 957 and $0.343 \%$ of cases sequenced and shared (https://www.gisaid.org/index.php?id=208 accessed June $25,2021)$. Some Egyptian genomic strains sequenced are similar

${ }^{1}$ Global initiative on sharing all influenza data. to isolates from the USA, Austria, Sweden, Saudi Arabia, and France (40). In Egypt, the D614G variant ${ }^{2}$ is the most dominant (40-42). T851, F307F, 15907G, P323L, Q57H, Q57L, Q822K, V5F, G15S, T148I, G212V, K2798R, and T5020I are examples of mutations reported in Egypt (41). D614G and P4715L mutations are linked to transmissibility, regardless of symptom variability (43), while Nsp6-L3606fs, spike-glycoprotein-V6fs, and nsp13S5398L variants may be linked to the worsening of clinical symptoms (43). The E3909G-nsp7 variant was shown to be more frequent in children and could explain why children recover so quickly (43).

In comparison with China (the epicenter of COVID-19 pandemic), the USA, Brazil, India, Italy, and France (the first countries in which the numbers of patients infected with COVID-19), Egypt ranks the 4th after China, India, the USA, and Brazil in terms of population. In terms of infected case percentage to population, Egypt ranks second-to-last after China, although, this does not reflect the whole picture of the epidemic in these countries. The COVID-19 recovery rate of Egypt is lower than China, India, Brazil, and Italy but similar to the United States. India and Egypt have the lowest mean age (28 and 25 years, respectively), and the majority of their people live in cities (65 and 57\%, respectively). However, the CFR percentage in Egypt (5.92\%) at the time of the writing of this article is higher than that of India (1.32\%) (Table 2). It could reflect, in our opinion, that high numbers of infected cases in Egypt pass officially undetected and homely recovered (44) and the dependency of most Egyptian public on symptom-based diagnoses, such as anosmia and dysgeusia. On one hand, the low COVID-19 mortality rate in Africa is due to the lower average age of the population, shorter life expectancy, and a few cardiovascular disease patients (45). On the other hand, milder cases are undetected, and death is delayed, making it difficult to anticipate the case fatality risk accurately (46). The mortality risk appears to be significantly increased by age (47, 48) and comorbidities (cardiovascular diseases, cancers, diabetes mellitus, and chronic lung diseases) $(49,50)$. Patients with one or more comorbidities had a worse survival rate (51). People aged 46 years and above represented $91.5 \%$ of coronavirus-related deaths in Egypt (52). SARS-CoV-2 coinfections with other infectious agents have been reported in Egypt (Table 3).

Most COVID-19 deaths in Africa have been in older people (55) with non-communicable diseases. In the absence of effective control measures, regions with older populations may have disproportionately more COVID-19 cases, especially in the later phases of an unmitigated epidemic (47). Early and chronic pathogen exposure, which leads to persistent immune cell activation in harsh conditions, triggers a robust regulatory immune response to fight excessive inflammation (56). Monocytes from Africans who have been highly exposed to pathogens could be less pro-inflammatory (57). Immune antibodies that neutralize SARS-CoV-2, which were produced against earlier related human coronaviruses, may exist in people who have not been exposed to SARS-CoV-2 due

${ }^{2}$ The replacement of aspartic acid by glycine at position 614 of the spike glycoprotein, which dominated the sequence. 


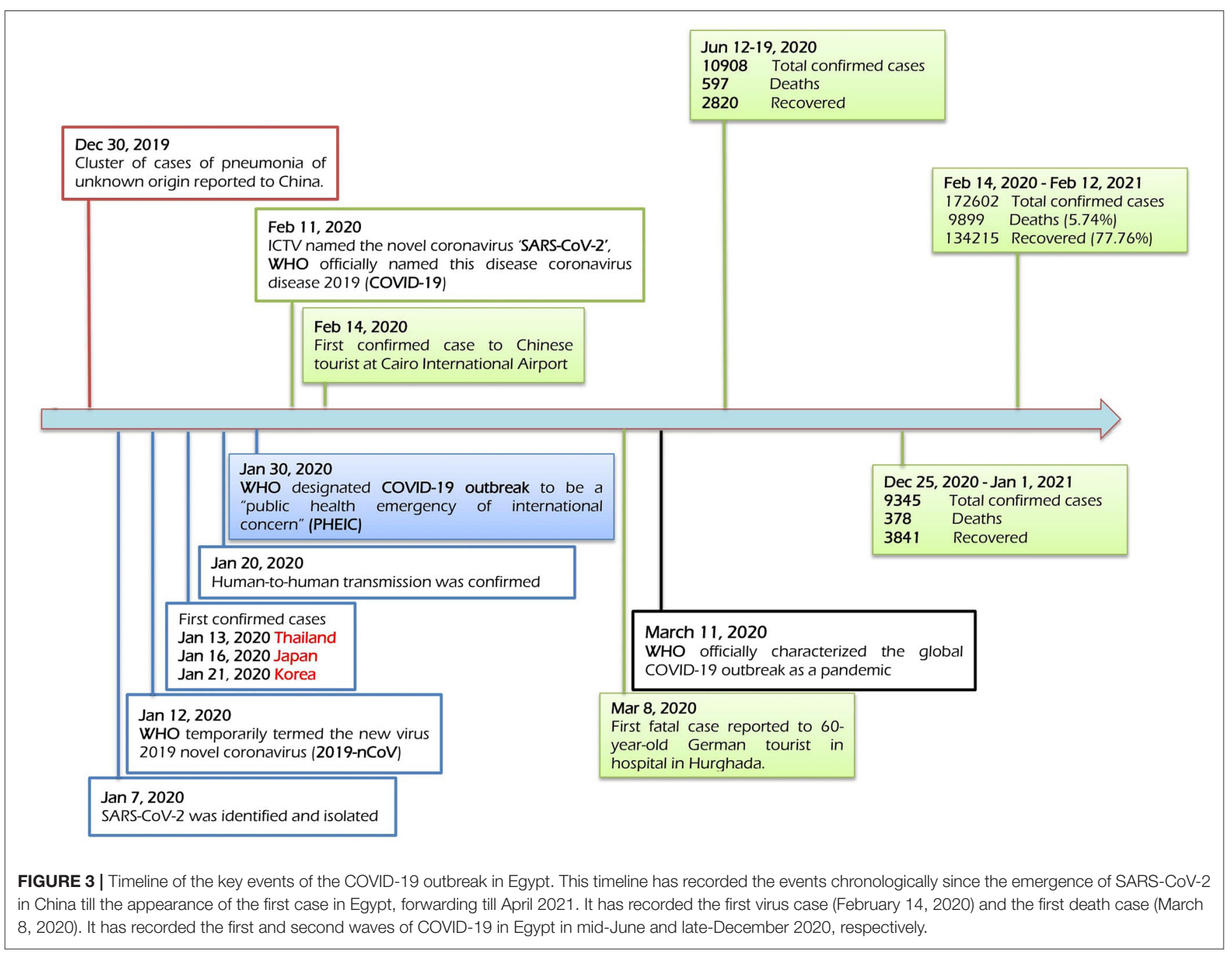

to immunological cross-reactivity (58), which could explain decreased susceptibility $(59,60)$.

Dr. Hala Zayed, the Minister of Health and Population, admitted that the infection of Egyptians with the virus is much more than what the government has stated (61), and the same meanings were carried by the words of the Minister of Higher Education and Scientific Research of Egypt, Khaled Abdel Ghaffar (62), and that seems normal according to insufficiency closure and social distancing. In addition, numerous mild and asymptomatic patients might not receive a timely diagnosis or healthcare, free movement of these people [ $\sim 40-45 \%$ (63)], such as presymptomatic travelers (64), helps in the spread of the virus to their contacts (fomites), concealing the true incidence and allowing disease progression. Therefore, asymptomatic people could not be diagnosed in January 2020, contributing to the spread of the epidemic. The viral shedding in the asymptomatic patients and survivors $(65,66)$ lasts for about 20 days, and this was significantly longer than that in the symptomatic patients (65). Generally, $81 \%$ of COVID- 19 cases are asymptomatic and have mild disease, while severe cases are 14\%, and critical and deceased cases are 5\% (17). Kissler et al. (59) suggested a short duration of immunity after SARS-CoV-2 infection, while Long et al. (65) suggested that asymptomatic individuals had a weaker immune response to SARS-CoV-2 infection. Lack of severe disease manifestations in clinically healthy people infected with SARS-CoV-2 could pose a significant risk to vulnerable populations with underlying medical conditions (diabetes, hypertension, or cardiovascular disease) $(24,67,68)$, proposing that the outbreak has several peaks.

Cruise ships carry different people into close contact for many days, making it easier for respiratory illnesses to spread (69). At least 60 laboratory-confirmed cases in the USA were linked to Nile River cruises in Egypt since February (70). Additionally, COVID-19 cases from Taiwan, UAE, France, and Japan were linked to travels from Egypt $(71,72)$. All the reported cases abroad are not within the estimates of the Egyptian government (73). El Gouna film festival was held in EL Gouna city from October 23, 2020, to October 31, 2020, which witnesses many Egyptian stars being infected with SARS-CoV-2. Later on, the 


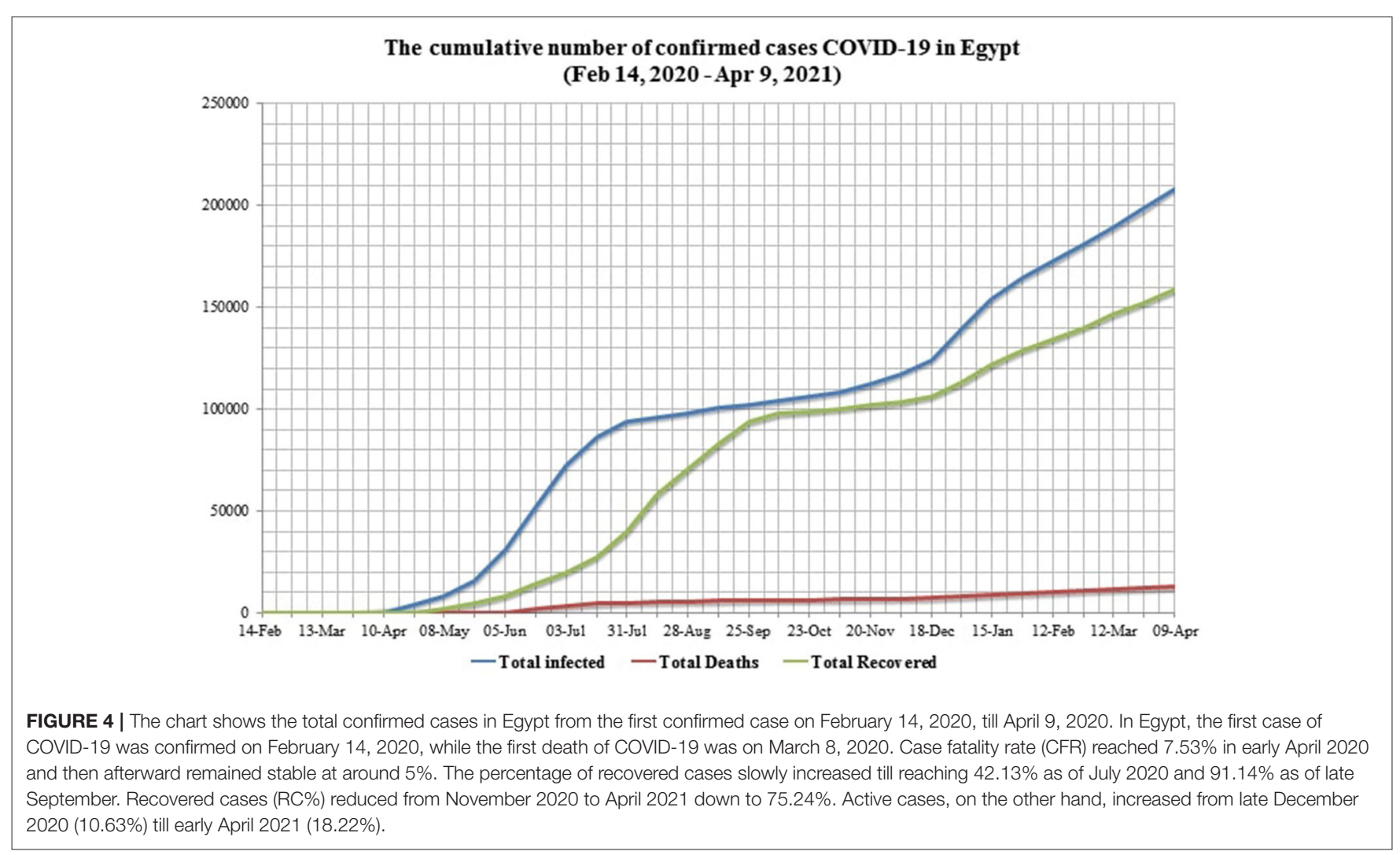

curve of SARS-CoV-2 infection exponentially increased to the second wave and probably that the patient tracing would not be efficiently performed. Recent reports (74) reported a slow and continual increase in infections and deaths in Sohag after a deadly train crash (75) in early April 2021. It is attributed to the large numbers of people who were present in Sohag on the same day of the collision, such as officials, relatives of the injured, and ordinary people who gathered around the crashed trains to rescuing the people.

"Fear doesn't prevent death. It prevents life," said Naguib Mahfouz. Egyptians are often affected by social distancing rules, as social gatherings and festivals are deeply ingrained in their culture. These include religious events, such as naming ceremonies, weddings, and communal prayers, especially on Fridays held at mosques and churches. According to the Pew Research Center, 62\% of Egyptians attend worship services weekly, and $72 \%$ say religion is very significant to their lives (39). Since the majority of citizens work in the informal business sector, such as traditional markets, strict lockout policies are difficult to enforce (37). Although, the critics were directed to the inability of the Egyptian government to provide the basic protective equipment to healthcare workers (HCWs), Egypt successfully hosted the 2021 IHF $^{3}$ World Men's Handball Championship, the first to involve 32 competing teams, from January 13, 2021, to January 31, 2021, without audience participation. The success of hosting this tournament is due

$\overline{{ }^{3} \text { International Handball Federation. }}$ to its launching behind doors besides releasing the Egypt 2021 COVID-19 Medical Precaution Plan.

\section{EGYPTIAN HEALTHCARE WORKERS}

Personal protective equipment (PPE) kit, surgical masks, N95 masks, and goggles are examples of personal protective control measures, especially for healthcare providers treating infected patients (76). Although, the efforts were carried out to combat the pandemic, inadequate PPEs (77) had a deleterious effect on the life (78) and mental health (79) of Egyptian Healthcare workers (EHCWs). According to the Egyptian Medical Syndicate (EMS), around 400 doctors have died of the SARS-CoV-2 virus infection, despite the failure of the $\mathrm{MOH}$ to divulge information on the number of medical professionals who died of COVID-19, including physicians, nurses, and technicians (80) (Table 4).

A recent study showed that $68.2 \%$ of SARS-CoV-2 infections in EHCWs are asymptomatic infections, and most infected EHCWs were nurses (81). Another study found that workers responsible for transportation of patients and cleaning, nurses, and administrative employees were more likely to get SARS-CoV2 infections higher than physicians. Moreover, $14.3 \%$ of frontline HCWs in the emergency department (ED) had contracted SARS-CoV-2 infections. This highlights the importance of more stringent infection control measures, education, and supervision to these HCWs alongside regular molecular testing of HCWs, even in the absence of symptoms, to protect HCWs from COVID-19 and reduce transmission from infected HCWs to 
A

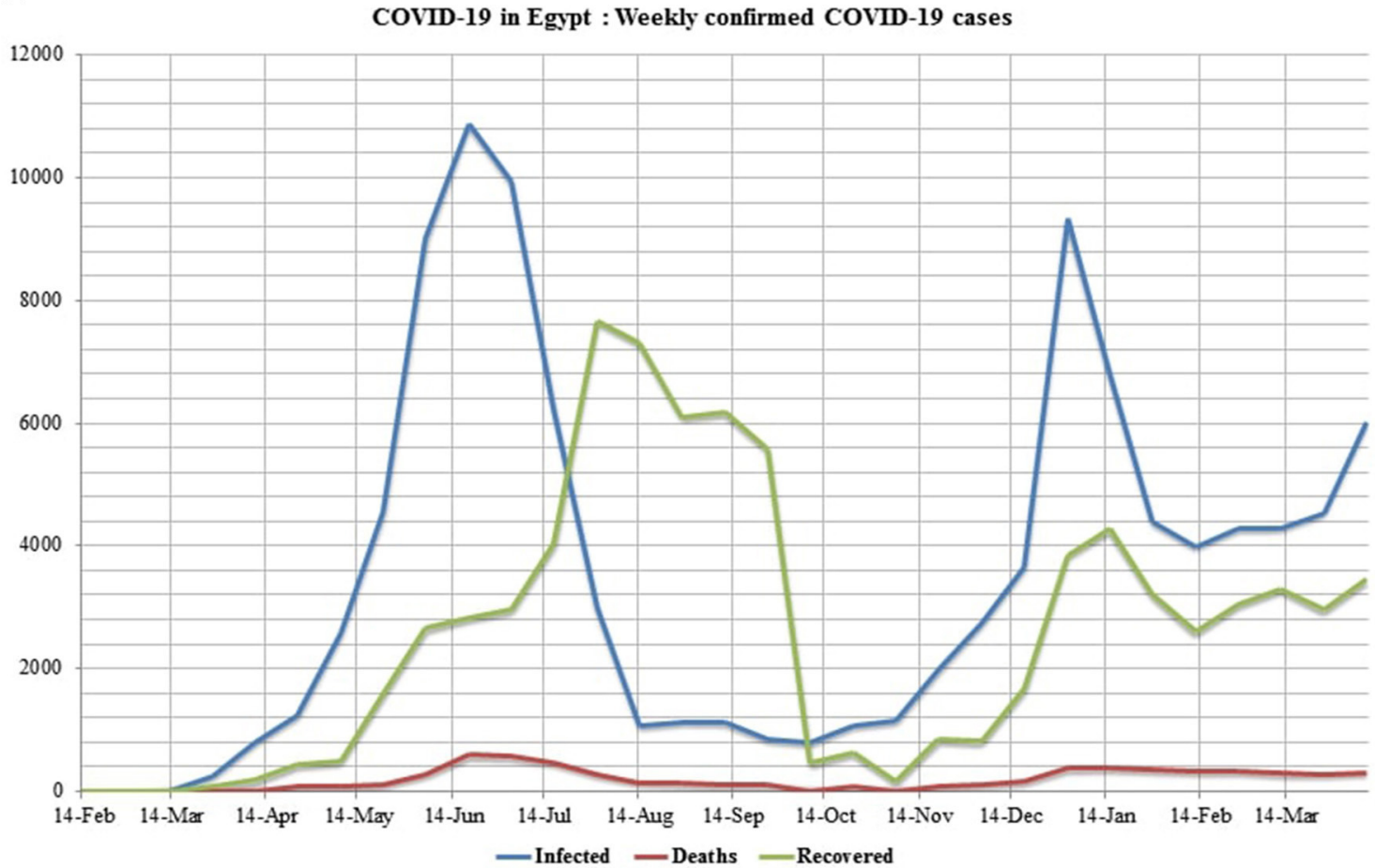

B

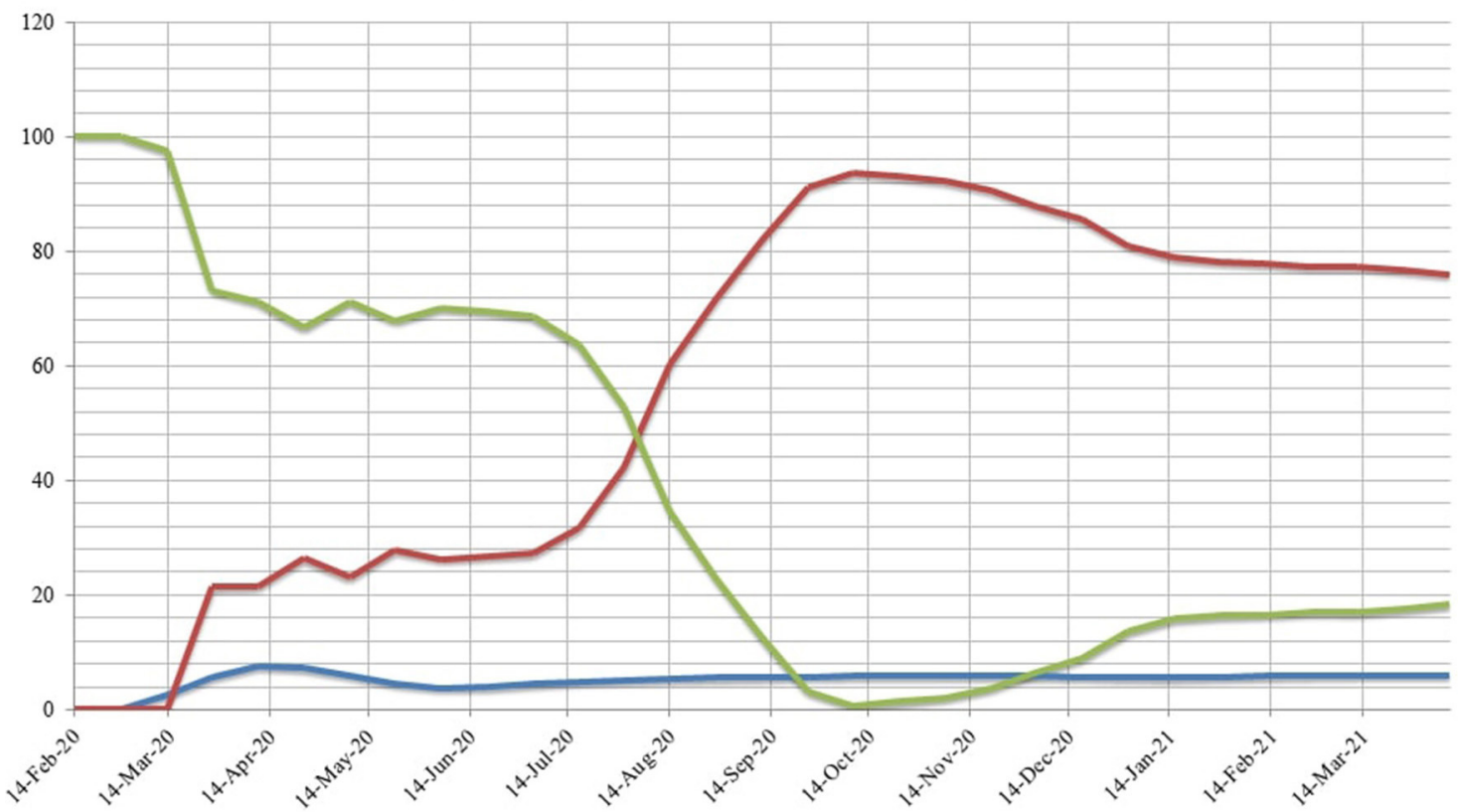

-Deaths \% - Recovered \% - Active cases \%

FIGURE 5 | Chart shows (A) the weekly confirmed cases and (B) the weekly percentages of CFR, active cases, and recovery. The chart of the weekly confirmed cases showed the first and second waves in June and December 2020, respectively. The highest percentage of recovered cases was found in August 2020, while the lowest was found in November 2020. The death rate is correlated with the waves, but it was higher in the first wave. The charts of weekly percentages showed that the percentage of active cases started with the first confirmed case in Egypt (February 14, 2020) while the percentage of death rate started with the first death $(8$ March). The lowest percentage of active cases was recorded in October 2020, when the percentage of recovered cases was the highest. 
TABLE 2 | COVID-19 statistics in Egypt, Italy, France, India, Brazil, the USA, and China.

\begin{tabular}{|c|c|c|c|c|c|c|c|}
\hline Country & Egypt & Italy & France & India & Brazil & USA & China \\
\hline Population & $102,334,404$ & $60,461,826$ & $65,273,511$ & 1,380,004,385 & $212,559,417$ & $331,002,651$ & $1,439,323,776$ \\
\hline \multirow[t]{2}{*}{ Infected } & 203,546 & $3,650,247$ & $4,741,759$ & $12,476,468$ & $12,912,379$ & $31,319,713$ & 101.773 \\
\hline & $0.2 \%$ & $6.04 \%$ & $7.26 \%$ & $0.9 \%$ & $6.07 \%$ & $9.46 \%$ & $0.007 \%$ \\
\hline \multirow[t]{2}{*}{ Death } & 12,084 & 110,704 & 96,280 & 164,610 & 328,366 & 567,697 & 4,841 \\
\hline & $5.94 \%$ & $3.03 \%$ & $2.03 \%$ & $1.32 \%$ & $2.54 \%$ & $1.8 \%$ & $4.76 \%$ \\
\hline Land area $\left(\mathrm{Km}^{2}\right)$ & 995,450 & 294,140 & 547,557 & $2,973,190$ & $8,358,140$ & $9,147,420$ & $9.388,211$ \\
\hline Mean age (yrs) & 25 & 47 & 42 & 28 & 33 & 38 & 38 \\
\hline Urban & $43 \%$ & $69 \%$ & $82 \%$ & $35 \%$ & $88 \%$ & $83 \%$ & $61 \%$ \\
\hline First case & Feb 14, 2020 & Feb 20, 2020 & Dec 27, 2019 Jan 24. 2020 & Jan 30. 2020 & Feb 25, 2020 & Jan 23, 2020 & Dec 8, 2019 \\
\hline
\end{tabular}

Data sources.

Worldometer. Population live updates (2020). Available at https://www.worldometers.info/coronavirus/ accessed on April 3, 2021.

Worldometer. COVID-19 coronavirus pandemic live updates (2020). Available at https://www.worldometers.info/population/ accessed on April 3, 2021.

https://www.worldometers.info/world-population/population-by-country/.

https://coronavirus.jhu.edu/map.html.

TABLE 3 | Reported coinfections with SARS-CoV-2 in Egypt.

\begin{tabular}{lll}
\hline Viruses & Influenza A (H1N1) \\
Bacteria & Klebsiella pneumonia \\
& Acinetobacter baumannii \\
& Staphylococcus aureus \\
& Streptococcus pneumonia \\
& Enterococcus faecalis \\
& Escherichia coli \\
& Pseudomonas aeruginosa \\
& Enterobacter cloacae \\
& Legionella \\
& Candida albicans \\
& Candida glabrata
\end{tabular}

the public $(82,83)$; that is why the Egyptian government has prioritized COVID-19 vaccination for HCWs and the elderly. A measles vaccine trial has been registered to prevent COVID-19 among HCWs in Egypt (84).

\section{THERAPEUTICS AND VACCINES}

Recently, exploring several vaccine platforms and advances in research studies has paved the way for developing COVID19 vaccines. Few of the approved vaccines are being used presently for vaccinating people in many countries, while other modern vaccines are in the pipeline of clinical trials and being conducted at various stages of development (85-89). However, there are currently no successful COVID-19 therapies or antivirals available for SARS-CoV-2. Various drugs and therapies, such as remdesivir, ivermectin, dexamethasone, convalescent plasma therapy, antibody-based immunotherapies, monoclonal antibodies, immunomodulatory agents, and others, have been found effective and utilized in an emergency to alleviate disease severity in COVID-19 patients; however, the choice of drugs and medicines are still been identified (3, 90-93) (Table 5). The use of antimalarial medications to treat malaria, notably artemisininbased combination therapy (ACT), is one of the possibilities that could explain the later onset and spread of the COVID-19 pandemic in African countries, such as Egypt (95).

During the ongoing pandemic, benefits of balanced nutrition, dietary supplements, nutraceuticals, plant extracts, medicinal herbs, traditional medicines, and other alternative/supportive regimens have also gained momentum owing to their promising ability to boost immunity and to promote better health and possessing antiviral properties and, therefore, have revealed a potential role in managing and treating patients infected with COVID-19 (96-101). Alternative and supportive approaches to prevent and control the spread of the pandemic disease are in urgent need. In Egypt, where a large population has cultural and religious perceptions, using natural substances as immunomodulators and medicines is considered an old approach. In the case of respiratory viral infections, certain natural products with immunostimulatory and antiviral properties are recommended. These may be used as a treatment and a preventative measure against viral infection and replication. Several traditional herbal medicines have been confirmed to have antiviral properties against the SARS-CoV-2 (97-102) (Table 6). Licorice salesman is a profession that is extensively located in Egypt alongside Egyptian spices dealers.

We suggest that the anti-inflammatory activities of some previous medicinal plants may be responsible for the improvement of some infected patients before lung tissue damage. Indomethacin, a non-steroidal anti-inflammatory drug, demonstrated potent antiviral activity against SARSCoV-2 when used in combination with herbal preparations (120). In a recent study, indomethacin and resveratrol showed promising efficacy against SARS-CoV-2 (120-122). In Egypt, indomethacin is widely used in the treatment of many rheumatic conditions (123). The African Programme for Onchocerciasis Control (APOC) includes a group of African countries that had 
TABLE 4 | A total of Egyptian physicians who had contracted or died from COVID-19 infections by mid-October 2020.

\begin{tabular}{|c|c|c|}
\hline Egyptian physicians & & \\
\hline \multirow[t]{2}{*}{ Total Infected Cases } & 3,575 & $1.625 \%$ of total Egyptian physicians $(220,000)$ \\
\hline & & $3.4 \%$ of total confirmed cases $(105,159)$ \\
\hline \multirow[t]{2}{*}{ Total Dead Cases } & 188 & $5.26 \%$ of total Egyptian physicians $(3,575)$ \\
\hline & & $3.08 \%$ of total confirmed cases $(6,099)$ \\
\hline
\end{tabular}

Data source.

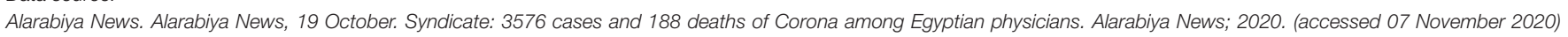
https://www.alarabiya.net/ar/arab-and-world/egypt/2020/10/19/. (Alarabiya News, 2020).

Worldometer. COVID-19 coronavirus pandemic live updates (2020). Available at https://www.worldometers.info/population/ Accessed on April 3, 2021.

TABLE 5 | Egyptian protocol for COVID-19 treatment/management.

\begin{tabular}{ll}
\hline Antipyretic & Paracetamol \\
Cough suppressants & Acelylcysteine \\
Anticoagulants & Enoxaparine \\
Fluid therapy & According to the condition of the \\
& patient \\
Multivitamins & Vitamin C or Zinc \\
Antiviral drugs and Antibiotics & Hydroxychloroquine - Ivermectin - \\
& Favipiravir - Remdesivir - \\
& Lopinavir/Ritonavir - Monoclonal \\
& antibodies - Convalescent plasma - \\
& Azithromycin - Nitazoxanide- \\
& Oseltamivir - Ribavirin - Interferon \\
& beta 1b - Doxycycline \\
Anti-inflammatory & Hydrocortisone - Dexamethasone - \\
& Methylprednisolone \\
Supplement & Lactoferrin \\
Immunosuppressive & Tocilizumab
\end{tabular}

Oxygen therapy

Mechanical ventilation

For patients with COVID-19, the Egyptian Ministry of Health approved a standard of a care treatment strategy that included (94).

By the end of May 2020, the Egyptian MOH guideline recommended that mild and some moderate cases will be managed by home isolation (53).

participated in an ivermectin campaign from 1995 to 2015 to combat onchocerciasis (124). Although, Egypt is a non-APOC country, the extra-label and extensive uses of ivermectin in the veterinary field in food-producing animals could have a role in the low incidence, but this speculation needs to be confirmed. Since December 2020, Egypt began to receive shipments of anti-COVID-19 vaccines, such as Sinopharm (BBIBP-CorV), AstraZeneca vaccine, and Sputnik V. Priority groups for vaccination are (A) medical staff at quarantine, fever, and chest hospitals, (B) patients with cancer or kidney or immunity problems, patients with chronic diseases, and the elderly, and (C) eventually all citizens above 18 years. As of March 2021, Egypt has started COVID-19 vaccine rollouts (125). Although, the country aims to vaccinate $40 \%$ of its population against COVID19 by the end of 2021, Egypt is one of the countries that suffer from vaccine hesitancy due to misinformation and false claims about vaccines used in Egypt (126). In February 2021, the first private post-COVID-19 clinic was established in Cairo to assist
TABLE 6 | Summary of some functional food plants of anti-inflammatory, immunomodulatory, and antiviral activities that could have anti-SARS-Co-2 activity.

\begin{tabular}{ll}
\hline Natural products & References \\
\hline Artemisiaannua (Sweet wormwood) & $(102,103)$ \\
Broussonetia papyrifera (Paper mulberry) & $(104)$ \\
Ocimum basilicum (Basil) & $(105)$ \\
Mentha piperita L. (Mentha) & $(106,107)$ \\
Zingiber officinalis (Ginger) & $(108-110)$ \\
Curcuma longa (Turmeric) & $(109-114)$ \\
Ficus carica (Fig) & $(109)$ \\
Allium sativum (Garlic) & $(107,109)$ \\
Glycine max (Soybean) & $(115)$ \\
Citrus aurantium (hesperidin and neohesperidin) & $(116)$ \\
Camellia sinensis (Tea) & $(109,116)$ \\
Oleanolic acid & $(116)$ \\
Trigonellafoenum-graecum (Fenugreek) & $(107)$ \\
Pelargonium sidoides & $(103)$ \\
Isatis indigotica (Woad) & $(103)$ \\
Glycyrrhiz aglabra (Liquorice) & $(103,107,109$, \\
Punica granatum L. (Pomegranate) & $117-119)$ \\
Piper nigrum L. (Black pepper) & $(109)$ \\
Pangifium aurantium L. (Bitter orange) & $(109)$ \\
\hline & $(109)$ \\
\hline
\end{tabular}

in the treatment of post-acute sequelae of SARS-CoV-2 infection (PASC) in patients who had not previously been hospitalized with COVID-19 (127). Post-COVID-19 complications and long-term consequences have primarily affected older patients (over 65 years of age) with comorbidities (127).

\section{LIMITATIONS OF THIS STUDY}

Although, this review article depended on the laboratoryconfirmed cases, many Egyptian people have caught SARS$\mathrm{CoV}-2$ infection and symptom-based diagnoses and homely isolated till recovery or hospitalized after the appearance of complications. 


\section{CONCLUSIONS}

Low COVID-19 prevalence in Egypt does not reflect the reality. Many SARS-CoV-2-infected people pass without any laboratory confirmations, and some cases depend on CT scans in informal laboratories. The wide traditional use of medicinal plants as hot or cold beverages and flavors added to foods could play a role in mitigating COVID-19 symptoms in Egyptians. The lower fatality rate in relation to the total population in Egypt (0.2\%) and India $(0.9 \%)$ might be due to the famous use of plants as prescriptions in both countries besides drinking of milk of cows, which may contain antibodies against this virus $(128,129)$. The lower incidence in Egypt may be attributed to the huge populations, low amount of screening testing, temperature and humidity, Bacille Calmette-Guerin (BCG) vaccine use (130), host genetics (131), misdiagnosis, and the young age of populations (132). Genetic variation has also been proven to alter the resistance of indigenous Africans to a variety of infectious diseases (133). The limitations of this study could make these findings a platform for adding insights to the existing knowledge. When living creatures put humanity in a tough problem across scientific history, other living creatures carry the solution for the problem. The interrelationship between human-animal-environment, including microbes and toxicants, is a very complicated issue that has not been clearly

\section{REFERENCES}

1. Wu F, Zhao S, Yu B, Chen Y-M, Wang W, Song Z-G, et al. A new coronavirus associated with human respiratory disease in China. Nature. (2020) 579:2659. doi: 10.1038/s41586-020-2008-3

2. The Gurdian. First Covid-19 Case Happened in November, China Government Records Show - Report. (2021). Available online at: https://www.theguardia n.com/world/2020/mar/13/first-covid-19-case-happened-in-november-chi na-government-records-show-report (accessed June 26, 2021).

3. Dhama K, Khan S, Tiwari R, Sircar S, Bhat S, Malik YS, et al. Coronavirus disease 2019-COVID-19. Clin Microbiol Rev. (2020) 33:e0002820. doi: 10.1128/CMR.00028-20

4. WHO. WHO COVID-19 Dashboard - Up to Date Data on Pandemic. (2021). Available online at: https://covid19.who.int/?gclid=CjwKCAiA65iBBhB-Eiw AW253W0GZ9U6TBkdh4YsVuarVQDugzsyLRuZF-ctQMSaXK8Lcz9kZ14 J9kRoC7uAQAvD_BwE (accessed June 25, 2021)

5. Zhu N, Zhang D, Wang W, Li X, Yang B, Song J, et al. China novel coronavirus investigating and research team. A novel coronavirus from patients with pneumonia in China, 2019. N Engl J Med. (2020) 382:727-33. doi: 10.1056/NEJMoa2001017

6. Guo Y-R, Cao Q-D, Hong Z-S, Tan Y-Y, Chen S-D, Jin H-J, et al. The origin, transmission and clinical therapies on coronavirus disease 2019 (COVID-19) outbreak-an update on the status. Mil Med Res. (2020) 7:1-10. doi: 10.1186/s40779-020-00240-0

7. Woo PCY, Lau SKP, Lam CSF, Lau CCY, Tsang AKL, Lau JHN, et al. Discovery of seven novel Mammalian and avian coronaviruses in the genus deltacoronavirus supports bat coronaviruses as the gene source of alphacoronavirus and betacoronavirus and avian coronaviruses as the gene source of gammacoronavirus and deltacoronavi. J Virol. (2012) 86:39954008. doi: 10.1128/JVI.06540-11

8. Graham RL, Baric RS. Recombination, reservoirs, and the modular spike: mechanisms of coronavirus cross-species understood till now. Human behavior against animals and the environment and even other humans constitutes the main factor in this interrelationship. According to many experts, human overpopulation is the worst environmental problem in the world (134). In some countries, the implementation of strict restrictions to control the outbreak is difficult and could be impossible. So, we need to turn our eyes toward boosting our immunity and improve our behaviors toward the environment. Surveillance and monitoring of various animal species for SARS-CoV-2 and integrating one health approach need to be strengthened and be widely implemented along with ramping up of the global vaccination drive, prevention, control, and mitigation strategies to halt the ongoing pandemic. The extensive attention given to the animal viruses alongside altered human behaviors, environmental changes, and adequate strengthening of global public health facilities (135-137) could block a future global viral pandemic.

\section{AUTHOR CONTRIBUTIONS}

AS: conceptualization, methodology, formal analysis, investigation, validation, writing - original draft, and writing review and editing. AM: writing - original draft, and writing review and editing. $\mathrm{KD}, \mathrm{SH}$, and $\mathrm{NM}$ : funding acquisition and writing - review and editing. All authors agreed to the published version of the manuscript. transmission. $\quad J \quad$ Virol. $\quad(2010) \quad 84: 3134-46 . \quad$ doi: $\quad$ 10.1128/JVI.01 394-09

9. Dhama K, Patel SK, Sharun K, Pathak M, Tiwari R, Yatoo MI, et al. SARSCoV-2 jumping the species barrier: zoonotic lessons from SARS, MERS, and recent advances to combat this pandemic virus. Travel Med Infect Dis. (2020) 37:101830. doi: 10.1016/j.tmaid.2020.101830

10. Morens DM, Daszak P, Taubenberger JK. Escaping Pandora's boxanother novel coronavirus. $N$ Engl J Med. (2020) 382:1293-5. doi: 10.1056/NEJMp2002106

11. Maxmen A. WHO report into COVID pandemic origins zeroes in on animal markets, not labs. Nature. (2021) 592:173-4. doi: 10.1038/d41586-021-00865-8

12. Zhang $\mathrm{T}, \mathrm{Wu} \mathrm{Q}$, Zhang $\mathrm{Z}$. Probable pangolin origin of SARS-CoV-2 associated with the COVID-19 outbreak. Curr Biol. (2020) 30:1346-51. doi: 10.1016/j.cub.2020.03.022

13. Lu H, Stratton CW, Tang Y. Outbreak of pneumonia of unknown etiology in Wuhan, China: the mystery and the miracle. J Med Virol. (2020) 92:401-2. doi: $10.1002 / j m v .25678$

14. Tiwari R, Dhama K, Sharun K, Iqbal Yatoo M, Malik YS, Singh R, et al. COVID-19: animals, veterinary and zoonotic links. Vet Q. (2020) 40:169-82. doi: 10.1080/01652176.2020.1766725

15. Sharun K, Tiwari R, Patel SK, Karthik K, Iqbal Yatoo M, Malik YS, et al. Coronavirus disease 2019 (COVID-19) in domestic animals and wildlife: advances and prospects in the development of animal models for vaccine and therapeutic research. Hum Vaccin Immunother. (2020) 16:3043-54. doi: $10.1080 / 21645515.2020 .1807802$

16. Sharun K, Tiwari R, Natesan S, Dhama K. SARS-CoV-2 infection in farmed minks, associated zoonotic concerns, and importance of the One Health approach during the ongoing COVID-19 pandemic. Vet Q. (2020) 41:50-60. doi: 10.1080/01652176.2020.1867776

17. Hu B, Guo H, Zhou P, Shi Z-L. Characteristics of SARS-CoV-2 and COVID19. Nat Rev Microbiol. (2020) 19:141-54. doi: 10.1038/s41579-020-00459-7 
18. Van Doremalen N, Bushmaker T, Morris DH, Holbrook MG, Gamble A, Williamson BN, et al. Aerosol and surface stability of SARS-CoV2 as compared with SARS-CoV-1. N Engl J Med. (2020) 382:1564-7. doi: 10.1056/NEJMc2004973

19. Liu Y, Ning Z, Chen Y, Guo M, Liu Y, Gali NK, et al. Aerodynamic analysis of SARS-CoV-2 in two Wuhan hospitals. Nature. (2020) 582:557-60. doi: 10.1038/s41586-020-2271-3

20. Wang W, Xu Y, Gao R, Lu R, Han K, Wu G, et al. Detection of SARSCoV-2 in different types of clinical specimens. JAMA. (2020) 323:1843-4. doi: 10.1001/jama.2020.3786

21. Bourouiba L, Dehandschoewercker E, Bush JWM. Violent expiratory events: on coughing and sneezing. J Fluid Mech. (2014) 745:537-63. doi: $10.1017 / \mathrm{jfm} .2014 .88$

22. Bourouiba L. Turbulent gas clouds and respiratory pathogen emissions: potential implications for reducing transmission of COVID-19. JAMA. (2020) 323:1837-8. doi: 10.1001/jama.2020.4756

23. Chen Y, Chen L, Deng Q, Zhang G, Wu K, Ni L, et al. The presence of SARS-CoV-2 RNA in the feces of COVID-19 patients. J Med Virol. (2020) 92:833-40. doi: 10.1002/jmv.25825

24. Li Q, Guan X, Wu P, Wang X, Zhou L, Tong Y, et al. Early transmission dynamics in Wuhan, China, of novel coronavirus-infected pneumonia. $N$ Engl J Med. (2020) 382:1199-207. doi: 10.1056/NEJMoa2001316

25. Kang M, Wei J, Yuan J, Guo J, Zhang Y, Hang J, et al. Probable evidence of fecal aerosol transmission of SARS-CoV-2 in a high-rise building. Ann Intern Med. (2020) 173:974-80. doi: 10.7326/M20-0928

26. Vivanti AJ, Vauloup-Fellous C, Prevot S, Zupan V, Suffee C, Do Cao J, et al. Transplacental transmission of SARS-CoV-2 infection. Nat Commun. (2020) 11:1-7. doi: 10.1038/s41467-020-17436-6

27. Kumar R, Yeni CM, Utami NA, Masand R, Asrani RK, Patel SK, et al. SARS-CoV-2 infection during pregnancy and pregnancyrelated conditions: concerns, challenges, management and mitigation strategies-a narrative review. J Infect Public Health. (2021) 14:863-75. doi: 10.1016/j.jiph.2021.04.005

28. Guan W, Ni Z, Hu Y, Liang W, Ou C, He J, et al. Clinical characteristics of coronavirus disease 2019 in China. N Engl J Med. (2020) 382:1708-20. doi: 10.1056/NEJMoa2002032

29. Dhama K, Patel SK, Pathak M, Yatoo MI, Tiwari R, Malik YS, et al. An update on SARS-CoV-2/COVID-19 with particular reference to its clinical pathology, pathogenesis, immunopathology and mitigation strategies. Travel Med Infect Dis. (2020) 37:101755. doi: 10.1016/j.tmaid.2020.101755

30. Yu P, Zhu J, Zhang Z, Han Y. A familial cluster of infection associated with the 2019 novel coronavirus indicating possible person-to-person transmission during the incubation period. J Infect Dis. (2020) 221:1757-61. doi: 10.1093/infdis/jiaa077

31. Docea AO, Tsatsakis A, Albulescu D, Cristea O, Zlatian O, Vinceti M, et al. A new threat from an old enemy: re-emergence of coronavirus. Int $\mathrm{J} \mathrm{Mol} \mathrm{Med.}$ (2020) 45:1631-43. doi: 10.3892/ijmm.2020.4555

32. Chen X, Laurent S, Onur OA, Kleineberg NN, Fink GR, Schweitzer F, et al. A systematic review of neurological symptoms and complications of COVID-19. J Neurol. (2020) 268:392-402. doi: 10.1007/s00415-02010067-3

33. Rabaan AA, Al-Ahmed SH, Garout MA, Al-Qaaneh AM, Sule AA, Tirupathi $\mathrm{R}$, et al. Diverse immunological factors influencing pathogenesis in patients with COVID-19: a review on viral dissemination, immunotherapeutic options to counter cytokine storm and inflammatory responses. Pathogens. (2021) 10:565. doi: 10.3390/pathogens 10050565

34. Thakur V, Ratho RK, Kumar P, Bhatia SK, Bora I, Mohi GK, et al. Multiorgan involvement in COVID-19: beyond pulmonary manifestations. J Clin Med. (2021) 10:446. doi: $10.3390 / \mathrm{jcm} 10030446$

35. Dhama K, Patel SK, Kumar R, Masand R, Rana J, Yatoo MI, et al. The role of disinfectants and sanitizers during COVID-19 pandemic: advantages and deleterious effects on humans and the environment. Environ Sci Pollut Res. (2021) 28:34211-28. doi: 10.1007/s11356-021-14429-w

36. Noorimotlagh Z, Jaafarzadeh N, Martínez SS, Mirzaee SA. A systematic review of possible airborne transmission of the COVID-19 virus (SARSCoV-2) in the indoor air environment. Environ Res. (2020) 139:110612. doi: $10.1016 /$ j.envres.2020.110612
37. Mbow M, Lell B, Jochems SP, Cisse B, Mboup S, Dewals BG, et al. COVID-19 in Africa: dampening the storm? Science. (2020) 369:624-6. doi: $10.1126 /$ science.abd3902

38. Gilbert M, Pullano G, Pinotti F, Valdano E, Poletto C, Boëlle P$\mathrm{Y}$, et al. Preparedness and vulnerability of African countries against importations of COVID-19: a modelling study. Lancet. (2020) 395:871-7. doi: 10.1016/S0140-6736(20)30411-6

39. Gaye Y-E, Agbajogu C, El Oakley R. COVID-19 on the Nile: review on the management and outcomes of the COVID-19 pandemic in the Arab Republic of Egypt from February to August 2020. Int J Environ Res Public Health. (2021) 18:1588. doi: 10.3390/ijerph18041588

40. Zekri A-RN, Amer KE, Hafez MM, Hassan ZK, Ahmed OS, Soliman HK, et al. Genomic characterization of SARS-CoV-2 in Egypt. J Adv Res. (2020) 30:123-32. doi: 10.1016/j.jare.2020.11.012

41. Laamarti M, Kartti S, Alouane T, Laamarti R, Allam L, Ouadghiri $\mathrm{M}$, et al. Genetic analysis of SARS-CoV-2 strains collected from North Africa: viral origins and mutational spectrum. bioRxiv. (2020). doi: 10.1101/2020.06.30.181123

42. Sallam M, Ababneh NA, Dababseh D, Bakri FG, Mahafzah A. Temporal increase in D614G mutation of SARS-CoV-2 in the Middle East and North Africa. Heliyon. (2021) 7:e06035. doi: 10.1016/j.heliyon.2021.e06035

43. Zekri A-RN, Mohanad M, Hafez MM, Soliman HK, Hassan ZK, Abouelhoda $\mathrm{M}$, et al. Genome sequencing of SARS-CoV-2 in a cohort of Egyptian patients revealed mutation hotspots that are related to clinical outcomes. Biochim Biophys Acta (BBA)-Molecular Basis Dis. (2021) 1867:166154. doi: 10.1016/j.bbadis.2021.166154

44. Fahim M, Ghonim HAES, Roshdy WH, Naguib A, Elguindy N, AbdelFatah $\mathrm{M}$, et al. Coinfection with SARS-CoV-2 and influenza $\mathrm{A}(\mathrm{H} 1 \mathrm{N1})$ in a patient seen at an influenza-like illness surveillance site in Egypt: case report. JMIR Public Heal Surveill. (2021) 7:e27433. doi: 10.2196/27433

45. Lawal Y. Africa's low COVID-19 mortality rate: a paradox? Int J Infect Dis. (2021) 102:118-22. doi: 10.1016/j.ijid.2020.10.038

46. Wilson N, Kvalsvig A, Barnard LT, Baker MG. Case-fatality risk estimates for COVID-19 calculated by using a lag time for fatality. Emerg Infect Dis. (2020) 26:1339. doi: 10.3201/eid2606.200320

47. Davies NG, Klepac P, Liu Y, Prem K, Jit M, Eggo RM. Age-dependent effects in the transmission and control of COVID-19 epidemics. Nat Med. (2020) 26:1205-11. doi: 10.1038/s41591-020-0962-9

48. Ghweil AA, Hassan MH, Khodeary A, Mohamed AO, Mohammed HM, Abdelazez AA, et al. Characteristics, outcomes and indicators of severity for COVID-19 among sample of ESNA quarantine hospital's patients, Egypt: a retrospective study. Infect Drug Resist. (2020) 13:2375. doi: 10.2147/IDR.S263489

49. Huang C, Wang Y, Li X, Ren L, Zhao J, Hu Y, et al. Clinical features of patients infected with 2019 novel coronavirus in Wuhan, China. Lancet. (2020) 395:497-506. doi: 10.1016/S0140-6736(20)30183-5

50. Ergönül Ö, Akyol M, Tanriöver C, Tiemeier H, Petersen E, Petrosillo N, et al. National case fatality rates of the COVID-19 pandemic. Clin Microbiol Infect. (2021) 27:118-24. doi: 10.1016/j.cmi.2020.09.024

51. Albadawy RM, Jadoon BA, Mogahed MM, Ibrahim ME, Essawy TS, Amin A, et al. The impact of comorbidities on the outcomes of Egyptian COVID19 patients: a follow-up study. J Environ Public Health. (2021) 2021:6662476. doi: $10.1155 / 2021 / 6662476$

52. Ahramonline. Second Coronavirus Wave in Egypt More Serious, Widespread: CAPMAS. (2021). Available online at: https://english.ahram.org.eg/ NewsContent/1/64/404931/Egypt/Politics-/Second-coronavirus-wave-inEgypt-more-serious-wid.aspx (accessed June 25, 2021).

53. Ramadan HK-A, Mahmoud MA, Aburahma MZ, Elkhawaga AA, ElMokhtar MA, Sayed IM, et al. Predictors of severity and co-infection resistance profile in COVID-19 patients: first report from upper Egypt. Infect Drug Resist. (2020) 13:3409. doi: 10.2147/IDR.S272605

54. Arashiro T, Nakamura S, Asami T, Mikuni H, Fujiwara E, Sakamoto S, et al. SARS-CoV-2 and Legionella co-infection in a person returning from a Nile cruise. J Travel Med. (2020) 27:taaa053. doi: 10.1093/jtm/ta aa053

55. Mehtar S, Preiser W, Lakhe NA, Bousso A, TamFum J-JM, Kallay O, et al. Limiting the spread of COVID-19 in Africa: one size mitigation 
strategies do not fit all countries. Lancet Glob Heal. (2020) 8:e881-3. doi: 10.1016/S2214-109X(20)30212-6

56. Yazdanbakhsh M, Kremsner PG, Van Ree R. Allergy, parasites, and the hygiene hypothesis. Science. (2002) 296:490-4. doi: $10.1126 /$ science.296.5567.490

57. Smolen KK, Cai B, Gelinas L, Fortuno ES, Larsen M, Speert DP, et al. Singlecell analysis of innate cytokine responses to pattern recognition receptor stimulation in children across four continents. J Immunol. (2014) 193:300312. doi: 10.4049/jimmunol.1400895

58. Grifoni A, Weiskopf D, Ramirez SI, Mateus J, Dan JM, Moderbacher CR, et al. Targets of $\mathrm{T}$ cell responses to SARS-CoV-2 coronavirus in humans with COVID-19 disease and unexposed individuals. Cell. (2020) 181:1489-501. doi: 10.1016/j.cell.2020.05.015

59. Kissler SM, Tedijanto C, Goldstein E, Grad YH, Lipsitch M. Projecting the transmission dynamics of SARS-CoV-2 through the postpandemic period. Science. (2020) 368:860-8. doi: 10.1126/science.abb5793

60. Nordling L. Africa's pandemic puzzle: why so few cases and deaths? Science. (2020) 369:756-7. doi: 10.1126/science.369.6505.756

61. Moderndiplomacy. Egypt's Search for a Fig Leaf: It's Not the Handball World Championship. (2021). Available online at: https://moderndiplomacy. eu/2021/01/17/egypts-search-for-a-fig-leaf-its- not- the-handball-worldchampionship/ (accessed June 25, 2021).

62. EgyptianStreets. 117,000 COVID-19 Cases in Egypt Say Estimates: Minister. (2020). Available online at: https://egyptianstreets.com/2020/06/01/100000covid-19-cases-in-egypt-say-estimates-minister/ (accessed June 25, 2021).

63. Oran DP, Topol EJ. Prevalence of asymptomatic SARS-CoV-2 infection: a narrative review. Ann Intern Med. (2020) 173:362-7. doi: 10.7326/M20-3012

64. Tong Z-D, Tang A, Li K-F, Li P, Wang H-L, Yi J-P, et al. Potential presymptomatic transmission of SARS-CoV-2, Zhejiang province, China, 2020. Emerg Infect Dis. (2020) 26:1052. doi: 10.3201/eid2605.2 00198

65. Long Q-X, Tang X-J, Shi Q-L, Li Q, Deng H-J, Yuan J, et al. Clinical and immunological assessment of asymptomatic SARS-CoV-2 infections. Nat Med. (2020) 26:1200-4. doi: 10.1038/s41591-020-0965-6

66. Zhou F, Yu T, Du R, Fan G, Liu Y, Liu Z, et al. Clinical course and risk factors for mortality of adult inpatients with COVID-19 in Wuhan, China: a retrospective cohort study. Lancet. (2020) 395:1054-62. doi: 10.1016/S0140-6736(20)30566-3

67. Munster VJ, Koopmans M, van Doremalen N, van Riel D, de Wit E. A novel coronavirus emerging in China-key questions for impact assessment. $N$ Engl J Med. (2020) 382:692-4. doi: 10.1056/NEJMp2000929

68. Arumugam VA, Thangavelu S, Fathah Z, Ravindran P, Sanjeev AMA, Babu S, et al. COVID-19 and the world with co-morbidities of heart disease, hypertension and diabetes. J Pure Appl Microbiol. (2020) 14:1623-38. doi: 10.22207/JPAM.14.3.01

69. Millman AJ, Kornylo Duong K, Lafond K, Green NM, Lippold SA, Jhung MA. Influenza outbreaks among passengers and crew on two cruise ships: a recent account of preparedness and response to an ever-present challenge. $J$ Travel Med. (2015) 22:306-11. doi: 10.1111/jtm.12215

70. Moriarty LF, Plucinski MM, Marston BJ, Kurbatova E V, Knust B, Murray EL, et al. Public health responses to COVID-19 outbreaks on cruise shipsworldwide, February-March 2020. Morb Mortal Wkly Rep. (2020) 69:34752. doi: 10.15585/mmwr.mm6912e3

71. Tuite AR, Ng V, Rees E, Fisman D, Wilder-Smith A, Khan K, et al. Estimation of the COVID-19 burden in Egypt through exported case detection. Lancet Infect Dis. (2020) 20:894. doi: 10.1016/S1473-3099(20)30233-4

72. Sekizuka T, Kuramoto S, Nariai E, Taira M, Hachisu Y, Tokaji A, et al. SARSCoV-2 genome analysis of Japanese travelers in Nile River cruise. Front Microbiol. (2020) 11:1316. doi: 10.3389/fmicb.2020.01316

73. Sahmoud T. Estimation of COVID-19 burden in Egypt. Lancet Infect Dis. (2020) 20:895-6. doi: 10.1016/S1473-3099(20)30318-2

74. Ahramonline. Coronavirus Infection Rate Continues to Rise in Sohag; COVID-Designated Hospitals to be Increased: Egypt's Health Minister. Available online at: https://english.ahram.org.eg/NewsContent/1/64/40970 6/Egypt/Politics-/Coronavirus-infection-rate-continues-to-rise-in-So.aspx (accessed April 20, 2021).

75. Arab News. Global Community Mourns with Arab World after Egypt's Deadly Sohag Train Crash. Available online at: https://www.arabnews.com/node/1832331/middle-east (accessed April 20, 2021).

76. Lu C, Liu X, Jia Z. 2019-nCoV transmission through the ocular surface must not be ignored. Lancet. (2020) 395:e39. doi: 10.1016/S0140-6736(20)30313-5

77. Refeai SA, Kamal NN, Ghazawy ERA, Fekry CM. Perception and barriers regarding infection control measures among healthcare workers in Minia city, Egypt. Int J Prev Med. (2020) 11:11. doi: 10.4103/ijpvm.IJPVM_320_18

78. Devi S. Egyptian health workers arrested after COVID-19 comments. Lancet. (2020) 396:369. doi: 10.1016/S0140-6736(20)31683-4

79. Elkholy H, Tawfik F, Ibrahim I, Salah El-din W, Sabry M, Mohammed S, et al. Mental health of frontline healthcare workers exposed to COVID19 in Egypt: a call for action. Int J Soc Psychiatry. (2020) 67:522-31. doi: $10.1177 / 0020764020960192$

80. Daily News. 30\% of COVID-19 Related Deaths Among Healthcare Workers Were Women: Planning Minister. (2021). Available online at: https:// dailynewsegypt.com/2021/03/21/30-of-covid-19-related-deaths-amonghealthcare-workers-were-women-planning-minister/ (accessed June 25, 2021).

81. Mostafa A, Kandil S, El-Sayed MH, Girgis S, Hafez H, Yosef M, et al. Universal COVID-19 screening of 4040 health care workers in a resource-limited setting: an Egyptian pilot model in a university with 12 public hospitals and medical centers. Int J Epidemiol. (2021) 50:50-61. doi: 10.1093/ije/dyaa173

82. Abdelmoniem R, Fouad R, Shawky S, Amer K, Elnagdy T, Hassan WA, et al. SARS-CoV-2 infection among asymptomatic healthcare workers of the emergency department in a tertiary care facility. J Clin Virol. (2021) 134:104710. doi: 10.1016/j.jcv.2020.104710

83. Kassem AM, Talaat H, Shawky S, Fouad R, Amer K, Elnagdy T, et al. SARS-CoV-2 infection among healthcare workers of a gastroenterological service in a tertiary care facility. Arab J Gastroenterol. (2020) 21:151-5. doi: 10.1016/j.ajg.2020.07.005

84. ClinicalTrials.gov. Identifier: NCT04357028. Measles Vaccine in HCW (MVCOVID19) 2020. (2020). Available online at: https://clinicaltrials.gov/ct2/ show/NCT04357028.

85. Iqbal Yatoo M, Hamid Z, Parray OR, Wani AH, Ul Haq A, Saxena A, et al. COVID-19-Recent advancements in identifying novel vaccine candidates and current status of upcoming SARS-CoV-2 vaccines. Hum Vaccin Immunother. (2020) 16:2891-904. doi: 10.1080/21645515.2020.17 88310

86. García-Montero C, Fraile-Martínez O, Bravo C, Torres-Carranza D, Sanchez-Trujillo L, Gómez-Lahoz AM, et al. An updated review of SARS$\mathrm{CoV}-2$ vaccines and the importance of effective vaccination programs in pandemic times. Vaccines. (2021) 9:433. doi: 10.3390/vaccines 9050433

87. Rawat K, Kumari P, Saha L. COVID-19 vaccine: a recent update in pipeline vaccines, their design and development strategies. Eur J Pharmacol. (2020) 892:173751. doi: 10.1016/j.ejphar.2020.173751

88. Ura T, Yamashita A, Mizuki N, Okuda K, Shimada M. New vaccine production platforms used in developing SARS-CoV-2 vaccine candidates. Vaccine. (2021) 39:197. doi: 10.1016/j.vaccine.2020.11.054

89. WHO. DRAFT Landscape of COVID-19 Candidate Vaccines. (2021). Available online at: https//www.who.int/publications $/ \mathrm{m} / \mathrm{item} /$ draft-landscape-of-covid-19-candidate-vaccines(accessed June 25, 2021).

90. Rabaan AA, Al-Ahmed SH, Sah R, Tiwari R, Yatoo MI, Patel SK, et al. SARSCoV-2/COVID-19 and advances in developing potential therapeutics and vaccines to counter this emerging pandemic. Ann Clin Microbiol Antimicrob. (2020) 19:1-37. doi: 10.1186/s12941-020-00384-w

91. Ghareeb DA, Saleh SR, Nofal MS, Kaddah MMY, Hassan SF, Seif IK, et al. Potential therapeutic and pharmacological strategies for SARSCoV2. J Pharm Investig. (2021) 51:281-96. doi: 10.1007/s40005-02100520-4

92. Pottoo FH, Abu-Izneid T, Sudqi AM, Javed MN, AlHajri N, Hamrouni AM. Immune system response during viral infections: immunomodulators, Cytokine Storm (CS) and Immunotherapeutics in COVID-19. Saudi Pharm J. (2021) 29:173-87. doi: 10.1016/j.jsps.2020.12.018

93. Iqbal Yatoo M, Hamid Z, Rather I, Nazir QUA, Bhat RA, Ul Haq A, et al. Immunotherapies and immunomodulatory approaches in clinical trials-a mini review. Hum Vaccin Immunother. (2021) 17:1897-909. doi: $10.1080 / 21645515.2020 .1871295$ 
94. Masoud HH, Elassal G, Zaky S, Baki A, Ibrahim H, Amin W, et al. Management Protocol for COVID-19 Patients. Version 14. Ministry of health and population (MOHP), Egypt (2020).

95. Gendrot M, Duflot I, Boxberger M, Delandre O, Jardot P, Le Bideau M, et al. Antimalarial artemisinin-based combination therapies (ACT) and COVID19 in Africa: in vitro inhibition of SARS-CoV-2 replication by mefloquineartesunate. Int J Infect Dis. (2020) 99:437-40. doi: 10.1016/j.ijid.2020.08.032

96. Dhama K, Karthik K, Khandia R, Munjal A, Tiwari R, Rana R, et al. Medicinal and therapeutic potential of herbs and plant metabolites/extracts countering viral pathogens-current knowledge and future prospects. Curr Drug Metab. (2018) 19:236-63. doi: 10.2174/1389200219666180129145252

97. Alkhatib A. Antiviral functional foods and exercise lifestyle prevention of Coronavirus. Nutrients. (2020) 12:2633. doi: 10.3390/nu12092633

98. Infusino F, Marazzato M, Mancone M, Fedele F, Mastroianni CM, Severino $\mathrm{P}$, et al. Diet supplementation, probiotics, and nutraceuticals in SARS-CoV-2 infection: a scoping review. Nutrients. (2020) 12:1718. doi: 10.3390/nu12061718

99. Anand AV, Balamuralikrishnan B, Kaviya M, Bharathi K, Parithathvi A, Arun M, et al. Medicinal plants, phytochemicals, and herbs to combat viral pathogens including SARS-CoV-2. Molecules. (2021) 26:1775. doi: 10.3390/molecules26061775

100. Capodice JL, Chubak BM. Traditional Chinese herbal medicine-potential therapeutic application for the treatment of COVID-19. Chin Med. (2021) 16:1-6. doi: 10.1186/s13020-020-00419-6

101. Thirumdas R, Kothakota A, Pandiselvam R, Bahrami A, Barba FJ. Role of food nutrients and supplementation in fighting against viral infections and boosting immunity: a review. Trends Food Sci Technol. (2021) 110:66-77. doi: 10.1016/j.tifs.2021.01.069

102. Li S, Chen C, Zhang H, Guo H, Wang H, Wang L, et al. Identification of natural compounds with antiviral activities against SARS-associated coronavirus. Antiviral Res. (2005) 67:18-23. doi: 10.1016/j.antiviral.2005.02.007

103. Khan T, Khan MA, Ullah N, Nadhman A. Therapeutic potential of medicinal plants against COVID-19: the role of antiviral medicinal metabolites. Biocatal Agric Biotechnol. (2020) 31:101890. doi: 10.1016/j.bcab.2020.101890

104. Park J-Y, Yuk HJ, Ryu HW, Lim SH, Kim KS, Park KH, et al. Evaluation of polyphenols from Broussonetia papyrifera as coronavirus protease inhibitors. J Enzyme Inhib Med Chem. (2017) 32:504-12. doi: 10.1080/14756366.2016.1265519

105. Chiang L, Ng L, Cheng P, Chiang W, Lin C. Antiviral activities of extracts and selected pure constituents of Ocimum basilicum. Clin Exp Pharmacol Physiol. (2005) 32:811-6. doi: 10.1111/j.1440-1681.2005.04270.x

106. $\mathrm{Li} \mathrm{Y}$, Liu $\mathrm{Y}$, Ma A, Bao $\mathrm{Y}$, Wang $\mathrm{M}$, Sun $\mathrm{Z}$. In vitro antiviral, anti-inflammatory, and antioxidant activities of the ethanol extract of Mentha piperita L. Food Sci Biotechnol. (2017) 26:1675-83. doi: 10.1007/s10068-017-0217-9

107. Aboelsoud NH. Herbal medicine in ancient Egypt. J Med Plants Res. (2010) 4:82-86. doi: 10.5897/JMPR09.013

108. Rasool A, Khan M-R, Ali M, Anjum A, Ahmed I, Aslam A, et al. Anti-Avian influenza virus H9N2 activity of aqueous extracts of Zingiber officinalis (Ginger) and Allium sativum (Garlic) in chick embryos. Pak J Pharm Sci. (2017) 30:1341-4.

109. Yang F, Zhang Y, Tariq A, Jiang X, Ahmed Z, Zhihao Z, et al. Food as medicine: a possible preventive measure against coronavirus disease (COVID-19). Phyther Res. (2020) 34:3124-36. doi: 10.1002/ptr.6770

110. Verma AK, Kumar V, Singh S, Goswami BC, Camps I, Sekar A, et al. Repurposing potential of Ayurvedic medicinal plants derived active principles against SARS-CoV-2 associated target proteins revealed by molecular docking, molecular dynamics and MM-PBSA studies. Biomed Pharmacother. (2021) 137:111356. doi: 10.1016/j.biopha.2021. 111356

111. Mounce BC, Cesaro T, Carrau L, Vallet T, Vignuzzi M. Curcumin inhibits Zika and chikungunya virus infection by inhibiting cell binding. Antiviral Res. (2017) 142:148-57. doi: 10.1016/j.antiviral.2017.03.014

112. Mathew D, Hsu W-L. Antiviral potential of curcumin. J Funct Foods. (2018) 40:692-9. doi: 10.1016/j.jff.2017.12.017

113. Joe B, Vijaykumar M, Lokesh BR. Biological properties of curcumin-cellular and molecular mechanisms of action. Crit Rev Food Sci Nutr. (2004) 44:97111. doi: 10.1080/10408690490424702
114. Wen C-C, Kuo Y-H, Jan J-T, Liang P-H, Wang S-Y, Liu H-G, et al. Specific plant terpenoids and lignoids possess potent antiviral activities against severe acute respiratory syndrome coronavirus. J Med Chem. (2007) 50:4087-95. doi: 10.1021/jm070295s

115. Takahashi S, Yoshiya T, Yoshizawa-Kumagaye $\mathrm{K}$, Sugiyama $\mathrm{T}$. Nicotianamine is a novel angiotensin-converting enzyme 2 inhibitor in soybean. Biomed Res. (2015) 36:219-24. doi: 10.2220/biomedres. 36.219

116. Wu C, Liu Y, Yang Y, Zhang P, Zhong W, Wang Y, et al. Analysis of therapeutic targets for SARS-CoV-2 and discovery of potential drugs by computational methods. Acta Pharm Sin B. (2020) 10:766-88. doi: 10.1016/j.apsb.2020.02.008

117. Hoever G, Baltina L, Michaelis M, Kondratenko R, Baltina L, Tolstikov GA, et al. Antiviral activity of glycyrrhizic acid derivatives against SARS- coronavirus. J Med Chem. (2005) 48:1256-9. doi: 10.1021/jm04 93008

118. Chrzanowski J, Chrzanowska A, Graboń W. Glycyrrhizin: an old weapon against a novel coronavirus. Phyther Res. (2021) 35:629-36. doi: $10.1002 /$ ptr.6852

119. Murck H. Symptomatic protective action of glycyrrhizin (Licorice) in Covid-19 infection? Front Immunol. (2020) 11:1239. doi: 10.3389/fimmu.2020.01239

120. Amici C, Di Caro A, Ciucci A, Chiappa L, Castilletti C, Martella V, et al. Indomethacin has a potent antiviral activity against SARS coronavirus. Antivir Ther. (2006) 11:1021-30.

121. Marinella MA. Indomethacin and resveratrol as potential treatment adjuncts for SARS-CoV-2/COVID-19. Int J Clin Pract. (2020) 74:e13535. doi: 10.1111/ijcp.13535

122. Xu T, Gao X, Wu Z, Selinger DW, Zhou Z. Indomethacin has a potent antiviral activity against SARS CoV-2 in vitro and canine coronavirus in vivo. bioRxiv. (2020). doi: 10.1101/2020.04.01.017624

123. Arafat H, Naim M, Shaalan A, Hosny S. Possible protective effect of capsaicin against indomethacin-induced damage in jejunum of adult male albino rats (histological and histochemical study). J Med Histol. (2020) 4:1-11. doi: 10.21608/JMH.2020.32344.1076

124. Guerrero R, Bravo LE, Muñoz E, Ardila EKG, Guerrero E. COVID19: the ivermectin African Enigma. Colomb Med. (2020) 51:e2014613. doi: $10.25100 / \mathrm{cm} . v 51 \mathrm{i} 4.4613$

125. Nabeth P, Hassan M, Adib K, Abubakar A, Brennan R. New COVID19 resurgence in the WHO Eastern Mediterranean region. Lancet. (2021) 397:1348-9. doi: 10.1016/S0140-6736(21)00679-6

126. Saied SM, Saied EM, Kabbash IA, Abdo SAE. Vaccine hesitancy: beliefs and barriers associated with COVID-19 vaccination among Egyptian medical students. J Med Virol. (2021) 93:4280-91. doi: 10.1002/jmv.26910

127. Aiash H, Khodor M, Shah J, Ghozy S, Sheble A, Hassan A, et al. Integrated multidisciplinary post-COVID-19 care in Egypt. Lancet Glob Heal. (2021) 9:e908-9. doi: 10.1016/S2214-109X(21)00206-0

128. Jawhara S. Can drinking microfiltered raw immune milk from cows immunized against SARS-CoV-2 provide short-term protection against COVID-19? Front. Immunol. (2020) 11:1888. doi: 10.3389/fimmu.2020.01888

129. Saied AA, Metwally AA, Mohamed HMA, Haridy MAM. The contribution of bovines to human health against viral infections. Environ Sci Pollut Res Int. (2021). doi: 10.1007/s11356-021-14941-z. [Epub ahead of print].

130. Medhat MA, El Kassas M. COVID-19 in Egypt: uncovered figures or a different situation? J Glob Health. (2020) 10:010368. doi: 10.7189/jogh.10.010368

131. Group SC-19G. Genomewide association study of severe Covid19 with respiratory failure. $N$ Engl J Med. (2020) 383:1522-34. doi: 10.1056/NEJMoa2020283

132. Diop BZ, Ngom M, Biyong CP, Biyong JNP. The relatively young and rural population may limit the spread and severity of COVID19 in Africa: a modelling study. BMJ Glob Heal. (2020) 5:e002699. doi: 10.1136/bmjgh-2020-002699

133. Gomez F, Hirbo J, Tishkoff SA. Genetic variation and adaptation in Africa: implications for human evolution and disease. Cold Spring Harb Perspect Biol. (2014) 6:a008524. doi: 10.1101/cshperspect.a008524

134. Minhas S. Could India be the origin of next COVID-19 like epidemic? Sci Total Environ. (2020) 728:138918. doi: 10.1016/j.scitotenv.2020.138918 
135. Allen T, Murray KA, Zambrana-Torrelio C, Morse SS, Rondinini C, Di Marco M, et al. Global hotspots and correlates of emerging zoonotic diseases. Nat Commun. (2017) 8:1-10. doi: 10.1038/s41467-017-00923-8

136. Morens DM, Folkers GK, Fauci AS. The challenge of emerging and re-emerging infectious diseases. Nature. (2004) 430:242-9. doi: 10.1038/nature02759

137. Parrish CR, Holmes EC, Morens DM, Park E-C, Burke DS, Calisher $\mathrm{CH}$, et al. Cross-species virus transmission and the emergence of new epidemic diseases. Microbiol Mol Biol Rev. (2008) 72:457-70. doi: 10.1128/MMBR.00004-08

Conflict of Interest: The authors declare that the research was conducted in the absence of any commercial or financial relationships that could be construed as a potential conflict of interest.
Publisher's Note: All claims expressed in this article are solely those of the authors and do not necessarily represent those of their affiliated organizations, or those of the publisher, the editors and the reviewers. Any product that may be evaluated in this article, or claim that may be made by its manufacturer, is not guaranteed or endorsed by the publisher.

Copyright (e) 2021 Saied, Metwally, Madkhali, Haque and Dhama. This is an openaccess article distributed under the terms of the Creative Commons Attribution License (CC BY). The use, distribution or reproduction in other forums is permitted, provided the original author(s) and the copyright owner(s) are credited and that the original publication in this journal is cited, in accordance with accepted academic practice. No use, distribution or reproduction is permitted which does not comply with these terms. 